Research Journal of Applied Sciences, Engineering and Technology 17(1): 7-12, 2020

DOI: $10.19026 /$ rjaset.17.6028

ISSN: 2040-7459; e-ISSN: 2040-7467

(C) 2020 Maxwell Scientific Publication Corp.

Submitted: July 7, 2019

Accepted: August 7, 2019

Published: February 15, 2020

\title{
Research Article \\ Adsorption of Cobalt Ion from Aqueous Solution Using Biomaterial of Microalgae Oscillatoria sp Isolated from Teluk Jakarta
}

\author{
${ }^{1}$ Askal Maimulyanti, ${ }^{2}$ Anton Restu Prihadi and ${ }^{1}$ Isna Nurhidayati \\ ${ }^{1}$ Department of Analytical Chemistry, Politeknik AKA Bogor, Indonesia \\ ${ }^{2}$ Department of Quality Assurance of Food Industry, Politeknik AKA Bogor, Indonesia
}

\begin{abstract}
The adsorption of cobalt onto biomaterial of microalga Oscillatoria $s p$ was investigated via batch experiment. Marine alga Oscillatoria $s p$ was isolated from Teluk Jakarta Indonesia. The characterization of the functional group with FTIR spectrum showed microalgae have a functional group of $\mathrm{O}-\mathrm{H}, \mathrm{C}=\mathrm{O}, \mathrm{COO}, \mathrm{C}-\mathrm{O}-\mathrm{C}, \mathrm{N}-$ $\mathrm{H}, \mathrm{C}-\mathrm{S}, \mathrm{C}-\mathrm{H}$ and $\mathrm{PO}_{4}{ }^{3-}$. Adsorption of cobalt ion was investigated as a function of time, $\mathrm{pH}$, initial cobalt concentration, the dosage of biosorbent, salinity dan shaking. Equilibrium and kinetic adsorption were obtained from the batch experiment. The cobalt adsorption followed the Langmuir and Freundlich, isotherm models. The Freundlich constant (Kf) and $\mathrm{n}$ were $0.1186(\mathrm{mg} / \mathrm{g})(\mathrm{L} \cdot \mathrm{mol})^{1 / \mathrm{n}}$ and $8.43 \mathrm{mg} / \mathrm{L}$, respectively. The maximum adsorption capacity was $4.71 \mathrm{mg} / \mathrm{g}$ at $\mathrm{pH}$ 8. Oscillatoria $s p$ could adsorb cobalt even at a lower concentration, indicating a good affinity for metal. Kinetic studies showed that the adsorption of cobalt ion followed a pseudo-firstorder with $\mathrm{k}_{1}=1.2 \times 10^{-3} \mathrm{~min}^{-1}$.
\end{abstract}

Keywords: Adsorption, biomaterial, cobalt, Oscillatoria $s p$

\section{INTRODUCTION}

The heavy metal contaminant is a problem in the aquatic environment because it can be accumulated in the human body and toxic above the tolerance level (Al-Rub et al., 2004). Cobalt is one of the heavy metal that must be reduced in the aquatic system. The higher of $\mathrm{Co}^{2+}$ solution was explored to remove $\mathrm{Co}^{2+}$ from solution (He et al., 2011). High-level cobalt concentration caused DNA damage (Simonsen et al., 2012; Leyssens et al., 2017). One technique to reduce cobalt contaminants in the aquatic is by adsorption technique using biosorbent. Biosorption is adsorption and accumulation process of pollutants from aqueous solution using the biological materials. Biosorption technique has an advantage in reducing heavy metal ions to a very low level (Feng and Aldrich, 2004). Many types of biomass have been studied for cobalt uptake as lemon peel (Bhatnagar et al., 2010), almond green hull (Ahmadpour et al., 2009) Blighia sapida (Jimoh et al., 2012).

Algae is one of the biosorbent in adsorb of toxic heavy metal because of it easy to grow and have a functional group in the wall cell. This functional group including carboxyl, sulfate and phosphate (Ahuja et al., 1999; Aravindhan et al., 2007). Many studies have shown that algae process high metal binding capacities
(Deng et al., 2007). Oscillatoria sp, a kind of cyanobacteria microalgae, is widely distributed in eutrophic freshwater and marine environment. Several research has been used Oscillatoria as biosorbent to uptake of the heavy metal such as $\mathrm{Cu}$ and $\mathrm{Zn}$ absorption (Ahuja et al., 1997; Ahuja et al., 2001; Al-Shammary and Abdulhay, 2016), Oscillatoria $s p$ for adsorption of Cd (Azizi et al., 2012), Pb (Kumar et al., 2011).

In this study, we will explore the potential of microalgae Oscillatoria $s p$ for the adsorb of cobalt (II) ion from aqueous solution. Marine microalga Oscillatoria $s p$ was isolated from Teluk Jakarta, Indonesia. Effect of $\mathrm{pH}$, adsorbent dosage, the concentration of cobalt, shaking and salinity will be performed in this study. Equilibrium isotherms for the adsorption of cobalt were measured experiment. Adsorption isotherms were determined with Langmuir and Freundlich equation.

\section{MATERIALS AND METHODS}

Prepared the material: Microalgae Oscillatoria $s p$ obtained from an Indonesian culture collection, LIPI Cibinong. It was grown at $25^{\circ} \mathrm{C}$ and $\mathrm{pH}$ adjusted to 8 . The algae were harvest after 14 days of growth. Thereafter, the algal pellet was washed with deionization distillation water and then used for metal

Corresponding Author: Askal Maimulyanti, Department of Analytical Chemistry, Politeknik AKA Bogor, Indonesia, Tel.: $+6281320717396$

This work is licensed under a Creative Commons Attribution 4.0 International License (URL: http://creativecommons.org/licenses/by/4.0/). 
uptake experiment. Characterization of functional groups from the biosorbent using FTIR. The chemical reagents used in this study are analytical reagent grade. The cobalt solution was prepared by dissolving the $\mathrm{Co}\left(\mathrm{NO}_{3}\right)_{2} \cdot 6 \mathrm{H}_{2} \mathrm{O}$ salt in distilled water. The initial ion concentration range $5-50 \mathrm{mg} / \mathrm{L}$. The $\mathrm{pH}$ of the solution was adjusted by adding $0.1 \mathrm{M} \mathrm{HCl}$ or $0.1 \mathrm{M} \mathrm{NaOH}$. The concentration of cobalt determined using an Atomic Absorption Spectrometer (AAS) (SHIMADZU A6000). Adsorption reading was taken in $240.7 \mathrm{~nm}$.

Adsorption study: The metal uptake experiment was performed in $250 \mathrm{~mL}$ Erlenmeyer flask containing 25 $\mathrm{mL}$ Co $50 \mathrm{mg} / \mathrm{L}$ and $0.25 \mathrm{~g}$ biosorbent. The solution becomes to $50 \mathrm{~mL}$ with added of demineralization water. The experiment was carried out in batches in different condition of time, concentration, $\mathrm{pH}$, amount of biosorbent, etc. The biosorbent with a known weight was left in contact with $50 \mathrm{~mL}$ of cobalt solution (5-50 $\mathrm{mg} / \mathrm{L}$ ) at $150 \mathrm{rpm}$. The mixture was shaken for $60 \mathrm{~min}$. The parameter adsorption consist of variation of contact time (30-120 $\mathrm{min})$, dosage of biosorbent (0.1-0.6 g), initial concentration of cobalt $(5-50 \mathrm{mg} / \mathrm{L})$, shaker $(50-$ $200 \mathrm{rpm}), \mathrm{pH}(3-8)$ and salinity $(0-30 \mathrm{~g} / \mathrm{L})$. Thereafter supernatant liquid was filtered and the concentration of cobalt was determined by AAS. The adsorbed quantities of cobalt ion were evaluated using the following equation:

$$
q e=\frac{(\mathrm{Co}-\mathrm{Ce}) \mathrm{V}}{W}
$$

where,

qe $=$ The amount or concentration of cobalt adsorbed onto the unit amount of microalgae Oscillatoria $s p(\mathrm{mg} / \mathrm{g})$

$\mathrm{Co}=$ The initial concentration of cobalt $(\mathrm{mg} / \mathrm{L})$

$\mathrm{V}=$ The volume of solution (L)

$\mathrm{w}=$ The weight of biosorbent (Liu et al., 2010; Jeppu and Clement, 2012)

The adsorption percentage of cobalt was adsorbed by biosorbent used the equation below:

$$
\text { Adsorption }(\%)=100 \frac{(C o-C e)}{C o}
$$

where,

$\mathrm{Ce}=$ Cobalt concentration in solution

Co $=$ The cobalt initial concentration

Adsorption isotherms: The Langmuir and Freundlich models were studies for equilibrium state. The Langmuir equation was shown below:

$$
\begin{aligned}
& \frac{C e}{q e}=\frac{1}{q_{m o n} \cdot K_{l}}+\frac{1}{q_{m o n}} . C e \\
& \ln q=\ln k+\frac{1}{n} \ln C
\end{aligned}
$$

where,

$\mathrm{Ce}=$ The solute concentration $(\mathrm{mg} / \mathrm{L})$ at equilibrium

qe $=$ The amount of solute at equilibrium $(\mathrm{mg} / \mathrm{g})$

$\mathrm{q}=$ Mon related to adsorption capacity

$\mathrm{K}=$ Langmuir constant

The Freundlich equation is an empiric model based on heterogeneous adsorption (Boudrahem, et al., 2011):

$$
\begin{aligned}
& q e=k f C e^{1 / n} \\
& \log q_{e}=\log K f+\frac{1}{n} \log C e
\end{aligned}
$$

Where $\mathrm{Kf}$ is the Freundlich constant indicated the adsorption intensity.

Kinetic study: In a different measuring flask, $25 \mathrm{~mL}$ of cobalt $50 \mathrm{ppm}$ (known concentration) and a known amount of adsorbent was taken periodic shaking. The solution was filtered and evaluated by atomic absorption spectrophotometer. The controlling mechanism of the metal adsorption process was studied by fitting first or second-order kinetic models. The linearity first-order kinetic model was shown in the below equation:

$$
\log (q o-q t)=\log q e-\frac{k 1}{2.003} t
$$

Where qt is the amount of adsorbate at time $\mathrm{t}(\mathrm{mg} / \mathrm{g})$, qe is the adsorption capacity at equilibrium $(\mathrm{mg} / \mathrm{g}) \mathrm{k} 1$ is the pseudo-first-order rate constant $\left(\mathrm{min}^{-1}\right)$ and $\mathrm{t}$ is the contact time (minute). The linearity second-order kinetic model is given as:

$$
\frac{t}{q t}=\frac{1}{K_{2} q^{2}}+\frac{1}{q_{e}} t
$$

Where $\mathrm{k}_{2}$ is the equilibrium rate constant of pseudosecond-order adsorption $\left(\mathrm{g} \mathrm{mg}^{-1} \cdot \mathrm{min}^{-1}\right)$.

\section{RESULTS AND DISCUSSION}

Characterization of biosorbent: Characterization of biosorbent was done using FTIR analysis. FTIR spectra of biosorbent Oscillatoria $s p$ is shown in Fig. 1. IR spectroscopy has been the method of choice for studying structure and interaction of molecules with identified of functional group (Banyay et al., 2003). The identification of functional group from Oscillatoria $s p$ can be seen in Table 1. The stretching vibration of C$\mathrm{H}$ indicated the methyl group and usually found in organic compounds (Coates, 2006). The peak of C-H stretching usually occurs below $3000 \mathrm{~cm}^{-1}$. The peaks $1510-1450$ is an aromatic stretch $(\mathrm{C}=\mathrm{C})$ and $850 \mathrm{~cm}^{-1}$ is $\mathrm{C}-\mathrm{H}$ aromatic (Coates, 2006). Biosorption of metal ion depends on the component and functional group of the biosorbent. This component including cellulose, 


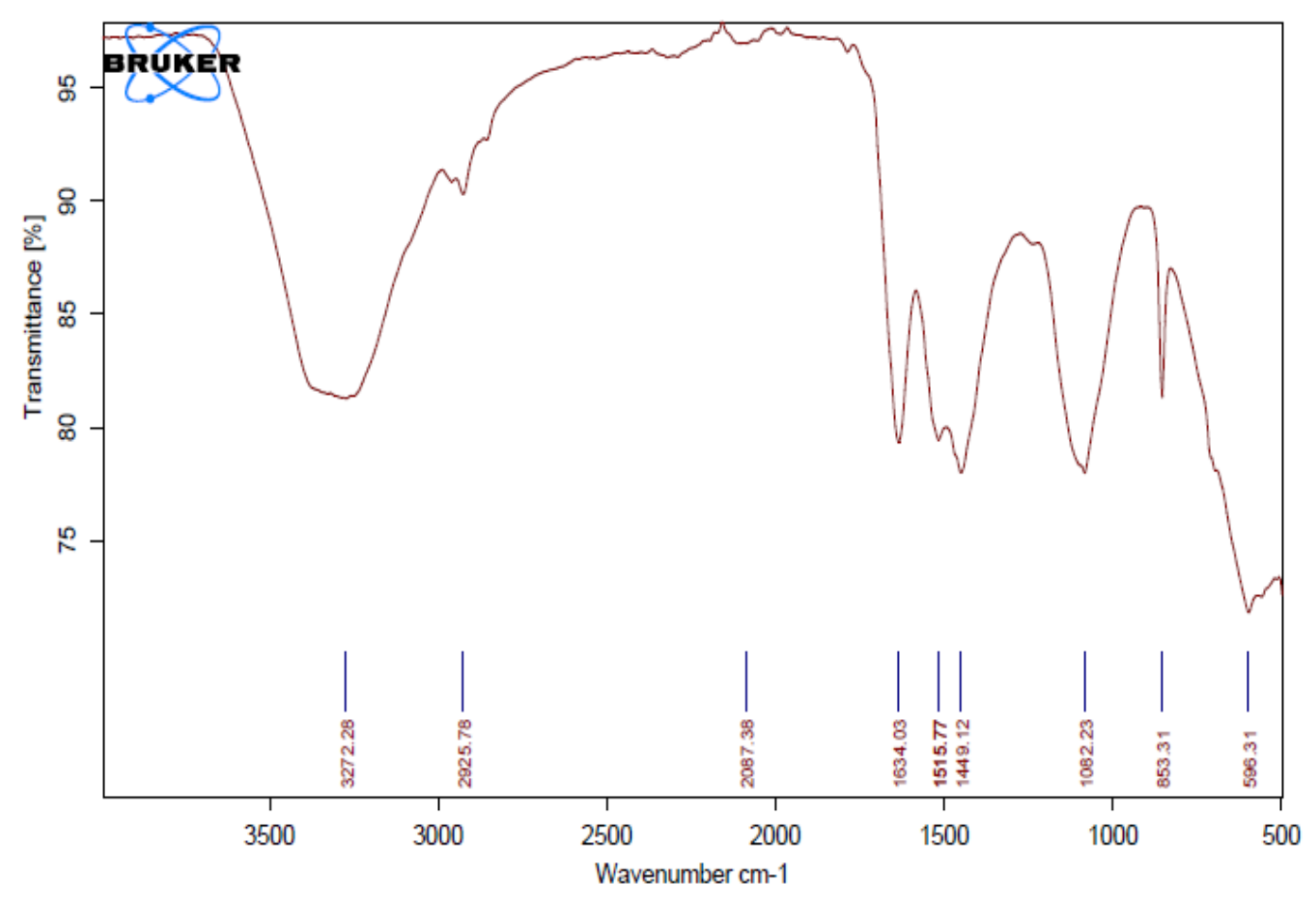

Fig. 1: FTIR analysis of Oscillatoria $s p$

Table 1: Identification of functional group of Oscillatoria $s p$

\begin{tabular}{|c|c|c|}
\hline Wavenumber $\left(\mathrm{cm}^{-1}\right)$ & $\begin{array}{l}\text { Functional } \\
\text { group }\end{array}$ & Chemical group \\
\hline 3272 & $\mathrm{O}-\mathrm{H}$ & Alcohol \\
\hline 2925 & $\mathrm{O}-\mathrm{CH}_{3}, \mathrm{C}-\mathrm{H}$ & Hydrocarbon \\
\hline 2087 & $\mathrm{C}-\mathrm{H}, \mathrm{N}-\mathrm{H}, \mathrm{C}=\mathrm{O}$ & $\begin{array}{l}\text { Hyrocarbon, amine, } \\
\text { carbonyl }\end{array}$ \\
\hline 1634 & $\mathrm{C}-\mathrm{C}$ & Hydrocarbon \\
\hline 1515 & $\mathrm{C}-\mathrm{H}$ & Hydrocarbon \\
\hline 1449 & $\mathrm{C}-\mathrm{H}, \mathrm{COO}$ & Hydrocarbon, carboxylate \\
\hline 1082 & $\mathrm{C}-\mathrm{N}, \mathrm{C}-\mathrm{O}-\mathrm{C}$ & Amine \\
\hline 853 & $\mathrm{PO}_{4}^{3-}, \mathrm{C}-\mathrm{O}-\mathrm{P}$ & Phosphates \\
\hline 596 & $\mathrm{C}-\mathrm{S}$, mineral & $\begin{array}{l}\text { Sulfur, Anorganic } \\
\text { compounds }\end{array}$ \\
\hline
\end{tabular}

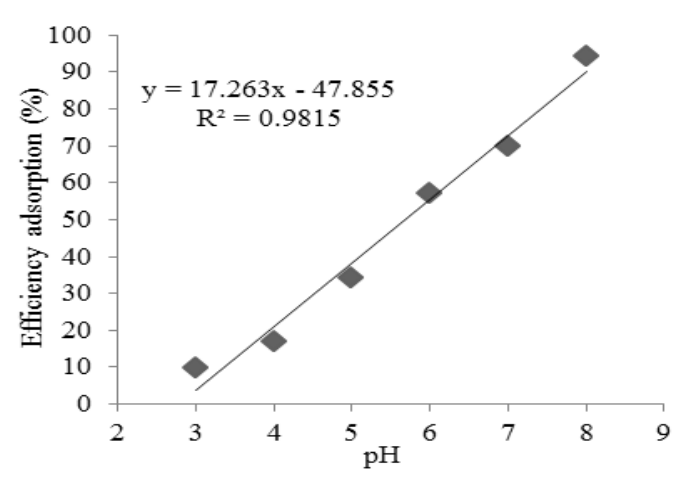

Fig. 2: Effect of $\mathrm{pH}$ on the cobalt adsorption into Oscillatoria sp.

oxygen, nitrogen, sulfur or phosphorus (Wang and Chen, 2009). The most important of these groups including carboxyl, carbonyl, amine, amide, thiol and phosphonate (Volesky, 2007).
Adsorption study: The cobalt sorption is depended on $\mathrm{pH}$ solution. The effect of initial $\mathrm{pH}$ on cobalt sorption capacity was studied at $25 \mathrm{mg} / \mathrm{L}$ cobalt initial concentration and the result is shown in Fig. 2. The uptake of cobalt in the $\mathrm{pH}$ range of 2-8 was determined in this experiment.

Figure 2 shows the relationship between $\mathrm{pH}$ and cobalt absorption efficiency by Oscillatoria $s p$. Biosorbent dosage of $0.25 \mathrm{~g}$, the initial concentration of cobalt is $25 \mathrm{ppm}$ and the volume of solution is $50 \mathrm{~mL}$. An increase in $\mathrm{pH}$ caused an increase in the amount of cobalt absorbed. There is a linear correlation between $\mathrm{pH}$ and adsorption efficiency with a correlation of 0.9815 and equation $y=17.263 x-47.855$. The maximum efficiency is obtained at $\mathrm{pH} 8$ with the adsorption of $23.58 \%$ and adsorption capacity of 4.71 $\mathrm{mg} / \mathrm{g}$. The $\mathrm{pH}$ solution can affect of metal-binding sites between cobalt and biosorbent. The cell wall ligands are closely associated with hydronium ion at the low of $\mathrm{pH}$ (Al-Rub et al., 2004). The increase of $\mathrm{pH}$ resulted in an increase in biosorption level because of influences of negative surface charge of the functional group. At the low $\mathrm{pH}$ occurred the competition between protons and metal ions in the adsorption process (Feng and Aldrich, 2004).

Shaking is carried out to homogenize the solution and regulate the process of absorption of cobalt by Oscillatoria $s p$. The stirring range is carried out with variations of 50-250 rpm. The effect of shaking on cobalt adsorption by Oscillatoria $s p$ can be seen in Fig. 3. Based on the experiment, the optimum stirring was 


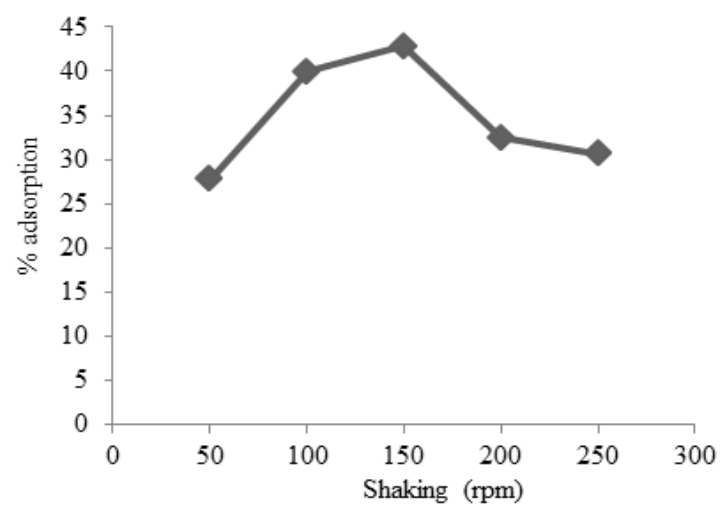

Fig. 3: Effect of shaking on the cobalt adsorption into Oscillatoria $\mathrm{sp}$.

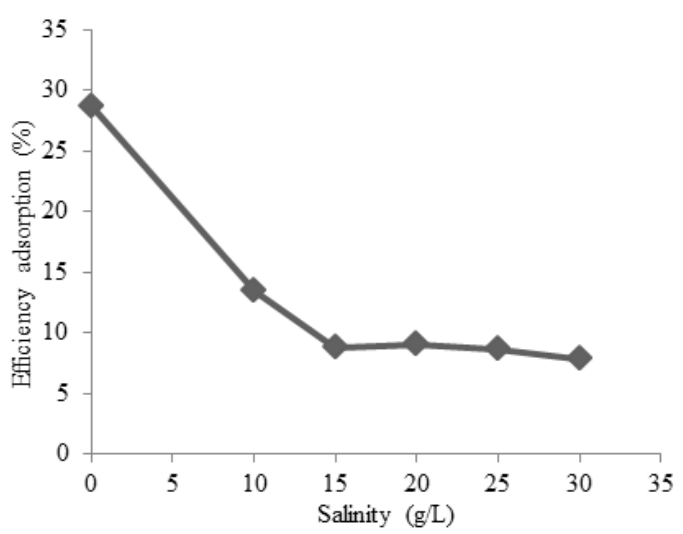

Fig. 4: Effect of salinity on the cobalt adsorption into Oscillatoria sp.

obtained at $150 \mathrm{rpm}$ with an adsorption efficiency of $41.81 \%$ and absorption capacity of $2.14 \mathrm{mg} / \mathrm{g}$.

Variation of salinity ion solution from $0-30 \mathrm{~g} / \mathrm{L}$. Figure 4 shows the greater the salinity, the smaller of cobalt absorbed by Oscillatoria $s p$. The optimum absorption was obtained in salinity $=0$ with optimum efficiency is $28.72 \%$ and absorption capacity of 1.43 $\mathrm{mg} / \mathrm{g}$. Analytical isotherms equation such as Langmuir and Freundlich isotherms are widely used for modeling adsorption data (Jeppu and Clement, 2012). According to the Langmuir model, sorption occurs uniformly on the active site of the sorbent and once a sorbate occupies a site. These model isotherms can be seen in Fig. 5 to 7.

Figure 5 shows the effect of initial cobalt concentration on adsorption capacity onto Oscillatoria $s p$. The result showed a linear correlation between the initial cobalt concentration and absorption capacity with $\mathrm{R}^{2}=0.976$ and equation $\mathrm{y}=0.1633 \mathrm{x}-0.5312$. The adsorption isotherm showed the adsorption molecule between the solid and liquid phase on the equilibrium state (Hameed et al., 2007). The applicability of the isotherm equation is compared with the correlation coefficient.

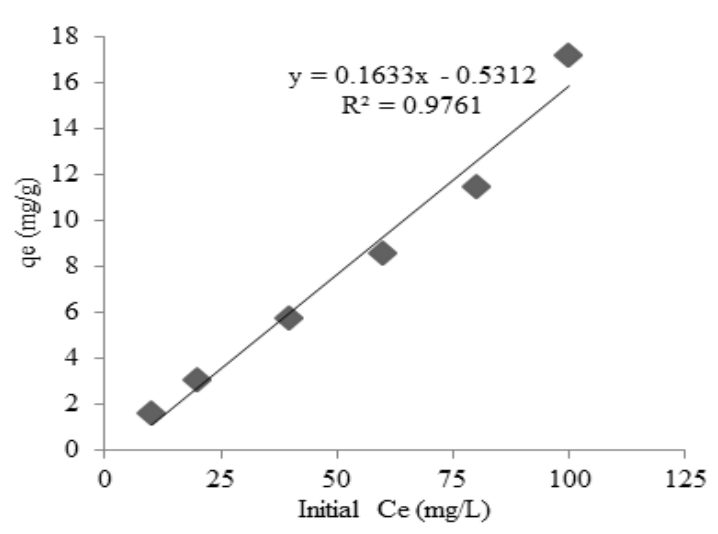

Fig. 5: Effect of concentration for the uptake of cobalt by Oscillatoria $s p$

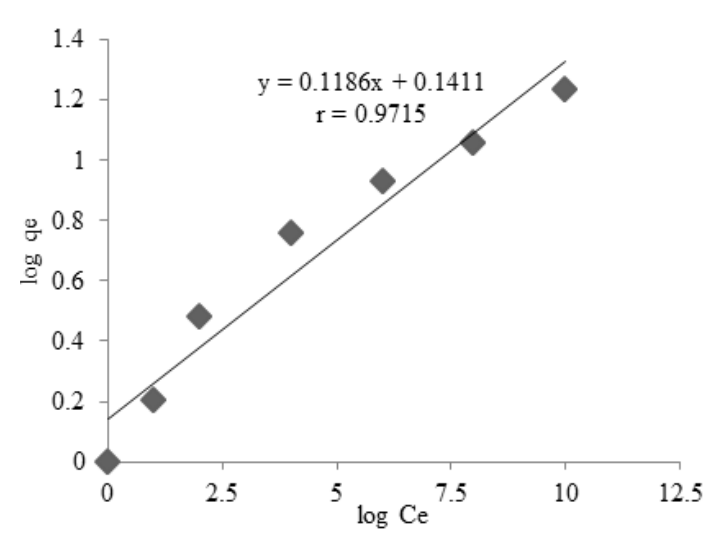

Fig. 6: Freundlich adsorption isotherm

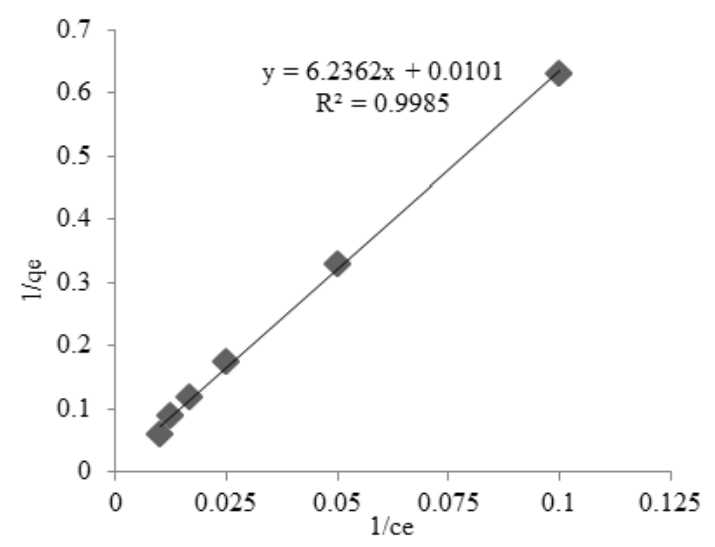

Fig. 7: Langmuir adsorption isotherm

In the Freundlich model, the cases linear plots were obtained which reveal the applicability of this isotherm on cobalt adsorption process (Mittal et al., 2007). The condition experiment was done in $\mathrm{pH}=5$, the amount of adsorbent $=2.5 \mathrm{~g}$ and time of 60 minutes. The correlation shown linear with $r=0.9715$ and equation of $y=0.1186 x+0.1411$. The linear plot in Ce vs log qe shows that the adsorption of cobalt onto Oscillatoria $s p$ follow the Freundlich isotherm model. The Freundlich 


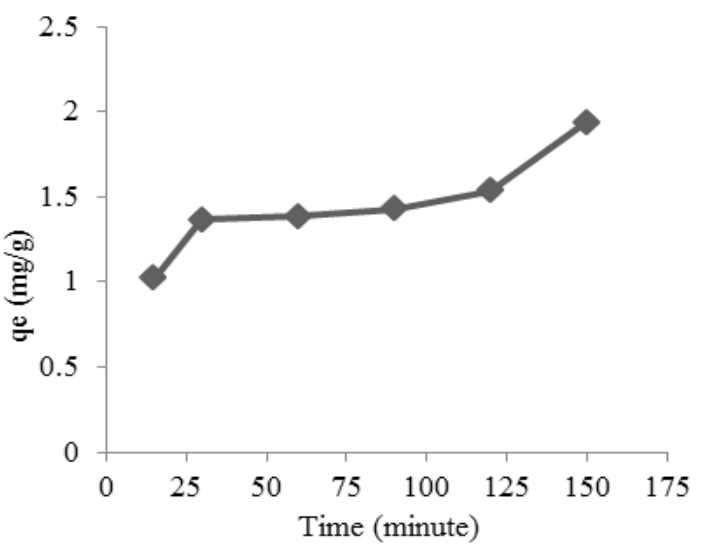

Fig. 8: Adsorption kinetic of cobalt on Oscillatoria $s p$

adsorption isotherm was also applied for the adsorption of cobalt onto Oscillatoria sp. Freundlich constant kf and $\mathrm{n}$ were found to be $0.1186(\mathrm{mg} / \mathrm{g})(\mathrm{L} \cdot \mathrm{mol})^{1 / \mathrm{n}}$ and $8.43 \mathrm{mg} / \mathrm{L}$, respectively.

Optimum adsorption capacity (qm) biosorbent of cobalt to adsorb of cobalt according to Langmuir model was $6.24 \mathrm{mg} / \mathrm{g}$. The slope and the intercept is $6.24 \mathrm{mg} / \mathrm{g}$ and $0,01 \mathrm{~L} / \mathrm{mg}$, respectively, that it indicated Q max and $b$. The Langmuir parameters can be used to knowing the affinity between the biosorbent and adsorbate. It can be used to suggests of the adsorption process is monolayer (Kalavathy et al., 2005; Ahalaya et al., 2010). The linear isotherm model is an alternative mathematical approach to predict the overall adsorption behavior (Chen, 2015).

Kinetic of adsorption: The kinetic parameters were calculated by monitoring the effect of contact time, amount of adsorbent and concentrations of adsorbate solution on adsorption of cobalt. Figure 8 shows the effect of contact time on cobalt absorption by Oscillatoria $s p$. The increase in contact time shows the greater of cobalt absorbed. The optimum contact time is obtained by incubation for 120 min with an absorption capacity of $1.9338 \mathrm{mg} / \mathrm{g}$. In can be inferred that the cobalt could ion could be adsorbed with a short time by using of Oscillatoria sp.

Figure 9 shows the effect of adsorbent dosage in cobalt adsorption by Oscillatoria $s p$. The algae dosage was $0.25 \mathrm{~g}$ and the initial concentration of $\mathrm{Co}^{2+}$ ion was approximately $25 \mathrm{mg} / \mathrm{L}$. The experiment shows increasing biosorbent dose increasing of cobalt adsorption in solution. The dose of biosorbent in the range of 0.1-0.6 $\mathrm{g}$ with the amount of adsorbent is $0.2983-0.3712 \mathrm{~g}$. This adsorption involved in the mass transfer of ions from aqueous into the surface of biosorbent (Liu et al., 2010).

The kinetics of adsorption describes the rate of cobalt ions uptake on Oscillatoria $s p$ microalgae and this rate control by the equilibrium time. The kinetic model of cobalt adsorption can be seen in Fig. 10. The kinetic model indicates the behavior of the adsorbent in

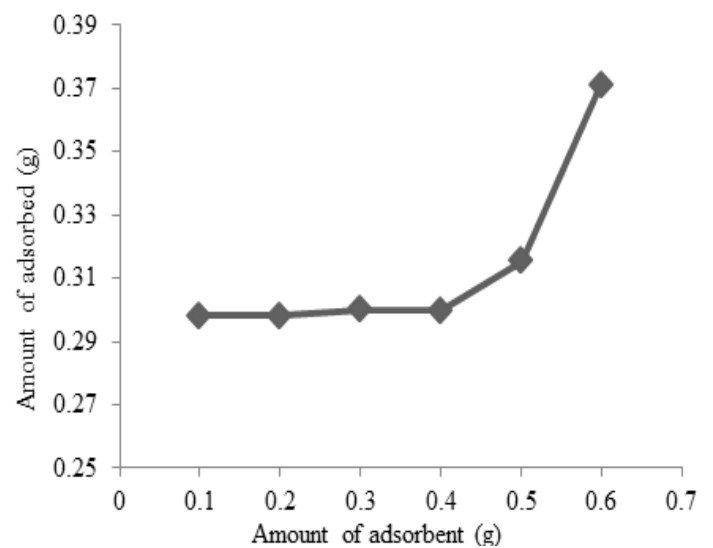

Fig. 9: Effect of adsorbent dosage for the adsorption of cobalt

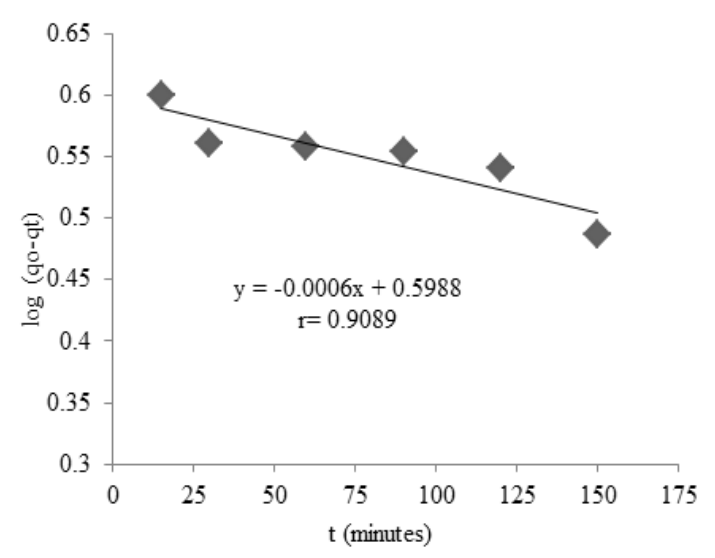

Fig. 10: The kinetic model of cobalt adsorption

the adsorption process (Aravindhan et al., 2007). The first-order rate, constant $\left(\mathrm{k}_{1}\right)$ and qe were determined from the slope and intercept of the plot (qo-qt) versus time contact. Kinetic studies showed that the adsorption followed a pseudo-first-order. The first-order rate constant $\mathrm{k}_{1}$ can be found in the experiment was $1.2 \times 10^{-3}$ $\min ^{-1}$.

\section{CONCLUSION}

The experimental result shows that microalgae of Oscillatoria $s p$ is an alternative for the removal of cobalt was depend on contact time, $\mathrm{pH}$, adsorbent dosage and initial cobalt concentration. Analysis of functional group from biosorbent shows the peaks of hydroxide, carboxyl and carbonyl ions. This functional group is an important role in the biosorption of cobalt ion. The adsorption models of cobalt ion with Oscillatoria $s p$ followed the Langmuir and Freundlich isotherms. The kinetic rate shows the pseudo-firstorder.

\section{ACKNOWLEDGMENT}

This research received financial support from Politeknik AKA Bogor, Indonesia. 


\section{CONFLICT OF INTEREST}

No potential conflict of interest was reported by the authors.

\section{REFERENCES}

Ahalaya, N., R.D. Kanamadi and T.V. Ramachandra, 2010. Removal of hexavalent chromium using coffee husk. Int. J. Environ. Pollut., 43: 106-117.

Ahmadpour, A., M. Tahmasbi, T.R. Bastami and J.A. Besharati, 2009. Rapid removal of cobalt ion from aqueous solutions by almond green hull. J. Hazard. Mater., 166(2-3): 925-930.

Ahuja, P., R. Gupta and R.K. Saxena, 1997. Oscillatoria anguistissima: A promising $\mathrm{Cu}^{2+}$ biosorbent. Curr. Microbiol., 35(03): 151-154.

Ahuja, P., R. Gupta and R.K. Saxena, 1999. $\mathrm{Zn}^{2+}$ biosorption by Oscillatoria anguistissima. Process Biochem., 34(01): 77-85.

Ahuja, P., H. Mohapatra, R.K. Saxena and R. Gupta, 2001. Reduced uptake as a mechanism of zinc tolerance in Oscillatoria anguistissima. Curr. Microbiol., 43(05): 305-310.

Al-Rub, F.A.A., M.H. El-Naas, F. Benyahia and I. Ashour, 2004. Biosorption of nickel on blank alginate beads, free and immobilized algal cells. Process Biochem., 39(11): 1767-1773.

Al-Shammary, M.A. and H.S. Abdulhay, 2016. Bioremoval of copper and zinc by filamentous alga Oscillatoria limnetica. World J. Experi. Biosci., 4(1): 37-39.

Aravindhan, R., J.R. Rao and B.U. Nair, 2007. Removal of basic yellow dye from aqueous solution by sorption on green alga Caulerpa Scalpelliformis. J. Hazard. Mater., 142(1-2): 68-76.

Azizi, S.N., A.H. Colagar and S.M. Hafeziyan, 2012. Removal of $\mathrm{Cd}(\mathrm{II})$ from aquatic system using Oscillatoria sp. biosorbent. Sci. World J., 2012: 17.

Banyay, M., M. Sarkar and A. Graslund, 2003. A library of IR bands of nucleic acids in solution. Biophys. Chem., 104(2): 477-488.

Bhatnagar, A., A.K. Minocha and M. Sillanpaa, 2010. Adsorptive removal of cobalt from aqueous solution by utilizing lemon peel as biosorbent. Biochem. Eng. J., 48(2): 181-186.

Boudrahem, F., A. Soualah and F. Aissani-Benissad, 2011. $\mathrm{Pb}$ (II) and $\mathrm{Cd}(\mathrm{II})$ removal from aqueous solutions using activated carbon developed from coffee residue activated with phosphoric acid and zinc chloride. J. Chem. Eng. Data, 56: 1946-1955.

Chen, X., 2015. Modeling of experimental adsorption isotherm data. Information, 6: 14-22.

Coates, J., 2006. Interpretation of Infrared Spectra, a Practical Approach. Encyclopedia of Analytical Chemistry. Jhon Willey and Sons Ltd., USA, pp:123.
Deng, L., Y. Su, H. Su, X. Wang and X. Zhu, 2007. Sorption and desorption of lead (II) from wastewater by green algae Cladophora fascicularis. J. Hazard. Mater., 143(1-2): 223-225.

Feng, D. and C. Aldrich, 2004. Adsorption of heavy metals by biomaterials derived from the marine alga Ecklonia maxima. Hydrometallurgy, 73(1-2): 1-10.

Hameed, B.H., A.T.M. Din and A.L. Ahmad, 2007. Adsorption of methylene blue onto bamboo-based activated carbon: Kinetics and equilibrium studies. J. Hazard. Mater., 141(03): 819-825.

He, M., Y. Zhu, Y. Yang, B. Han and Y. Zhang, 2011. Adsorption of cobalt (II) ions from aqueous solution by polygarkite. Appl. Clay Sci., 54: 292296.

Jeppu, G.P. and T.P. Clement, 2012. A modified Langmuir-Freundlich isotherm model for simulating pH-dependent adsorption effects. J. Contamin. Hydrol., 129-130: 46-53.

Jimoh, T.O., A.T. Buoro and M. Muriana, 2012. Utilization of Blighia sapida (akee apple) pod in the removal of lead, cadmium and cobalt ions from aqueous solution. J. Environ. Chem. Ecotoxicol., 4(10): 178-187.

Kalavathy, M.H., T. Karthikeyan, S. Rajgopal and L.R. Miranda, 2005. Kinetic and isotherm studies of $\mathrm{Cu}$ (II) adsorption onto $\mathrm{H}_{3} \mathrm{PO}_{4}$-activated rubber wood sawdus. J. Colloid Interf. Sci., 292(2): 354-362.

Kumar, M.S., K. Rajeshwari, S. Johnson, N. Thajuddin and M. Gunasekaran, 2011. Removal of Pb (II) by immobilized and free filaments of marine Oscillatoria sp. NTMS01 and phormidium sp. NTMS02. Bull. Environ. Contam. Toxicol., 87(3): 254-259.

Leyssens, L., B. Vinck, C.V.D. Straeten, F. Wuyts and L. Maes, 2017. Cobalt toxicity in humans-A review of the potential sources and systemic health effects. Toxicology, 387: 43-56.

Liu, Q.S., T. Zheng, P. Wang, J.P. Jiang and N. Li, 2010. Adsorption isotherm, kinetic and mechanism studies of some substituted phenols on activated carbon fibers. Chem. Eng. J., 157(2-3): 348-356.

Mittal, A., L. Kurup and J. Mittal, 2007. Freundlich and Langmuir adsorption isotherms and kinetics for the removal of tartrazine from aqueous solutions using hen feathers. J. Hazard. Mater., 146: 243-248.

Simonsen, L.O., H. Harbak and P. Bennekou, 2012. Cobalt metabolism and toxicology--A brief update. Sci.Total Environ., 432: 210-215.

Volesky, B., 2007. Biosorption and me. Water Res., 41(18): 4017-4029.

Wang, J. and C. Chen, 2009. Biosorbents for heavy metals removal and their future. Biotechnol. Adv., 27(02): 195-226. 